\title{
Abnormal visceral autonomic innervation in neurogenic faecal incontinence
}

\author{
C T M Speakman, M A Kamm
}

\begin{abstract}
Changes of denervation in the anal sphincter striated and smooth muscle in patients with neurogenic faecal incontinence are well established. This study aimed to determine if there is also a more proximal visceral autonomic abnormality. Thirty women with purely neurogenic faecal incontinence (prolonged pudendal nerve latencies and an intact sphincter ring) and 12 patients with neuropathic changes together with an anatomical disruption were studied. Two control groups consisted of 18 healthy volunteer women and 17 women with normal innervation but an anatomically disrupted sphincter. Rectal sensation was assessed using balloon distension and electrical mucosal stimulation, and anal sensation by electrical stimulation. Rectal compliance was studied to determine whether sensory changes were primary or caused by altered rectal wall viscoelastic properties. Anal canal pressure changes in response to both rectal distension and rectal electrical stimulation were measured to assess the intrinsic innervation of the internal anal sphincter. Patients with neurogenic incontinence alone had impaired rectal sensation to distension $(53.1 v 31.5 \mathrm{ml}, \mathrm{p}<0.05$, neurogenic $v$ controls) and to electrical stimulation $(24.4 v$ $14.8 \mathrm{~mA}, \mathrm{p}<0.005)$. Patients with neurogenic incontinence and sphincter disruption also showed impaired sensation compared with healthy controls $(55.8 \mathrm{ml} v 31.5 \mathrm{ml}, \mathrm{p}<0.05$ and $22.9 \mathrm{~mA} v 14.8 \mathrm{~mA}, \mathrm{p}<0.05)$. Patients with only a disrupted sphincter had normal visceral sensation to both types of testing. Both rectal compliance and the response of the internal anal sphincter to rectal distension and electrical stimulation were normal in all patient groups. This study suggests that there is a visceral sensory abnormality in patients with neurogenic incontinence which is not caused by altered rectal compliance. As evaluated in this study the intrinsic innervation of the internal anal sphincter is not affected in this process.
\end{abstract}

(Gut 1993; 34: 215-221)

Denervation of the pelvic floor striated muscles in patients with neurogenic faecal incontinence is well described. ${ }^{12}$ Proximal bowel motor and sensory functions, however, are also likely to play an important role in the maintenance of continence - the importance of rectal sensation in maintaining faecal continence was recognised by Goligher and Hughes 40 years ago. ${ }^{3}$ The external anal sphincter response to rectal stimulation is at least partly under voluntary control ${ }^{+}$and is closely related to rectal sensory function, ${ }^{5}$ indicating the importance of the afferent sensory pathways in this process. In patients with neuro- genic faecal incontinence preliminary evidence of an abnormality in visceral afferent pathways comes from a study which showed diminished external and sphincter recruitment when continence was threatened by a rise in intraabdominal pressure. ${ }^{6}$

The perception of rectal stimulation depends on the type of stimulus (for example distension or electrical stimulation), rectal compliance, and peripheral and central processing of sensory information. Variation in these parameters, together with variation in the type of patient populations studied, is probably responsible for the conflicting data on rectal sensation in patients with faecal incontinence. Although some studies have shown impaired rectal sensation in patients with faecal incontinence ${ }^{6-11}$ others have not found an abnormality. ${ }^{12-15}$

To clarify the relationship between anorectal sensation and faecal incontinence we have studied anorectal sensation, rectal compliance, and the response of the anal sphincter to rectal distension and electrical stimulation in four groups of subjects: patients with pure neurogenic faecal incontinence, those with faecal incontinence caused by an anatomically disrupted sphincter, patients with a mixture of pelvic neuropathy and anatomical disruption, and healthy control subjects.

We sought to determine whether rectal sensation is impaired in faecal incontinence; two types of sensory stimulation were applied to elucidate further the nature of any sensory defect. To determine whether the anal sphincter relaxes inappropriately with rectal stimulation the response of the anal sphincter to quantitated graded rectal stimulation was also assessed.

\section{Subjects}

\section{PATIENTS}

Fifty nine women with incontinence to solid stool referred to St Mark's Hospital were studied. Maximum resting anal pressure and maximum voluntary contraction pressures were measured using a closed, water filled system with a $4 \mathrm{~mm}$ diameter microballoon connected through a $2 \mathrm{~mm}$ non-compliant plastic catheter to a pressure transducer (Medex MX-848, Rossendale, UK) and a chart recorder (Devices MX4-73). To establish the presence of impaired innervation of the sphincter muscles pudendal nerve terminal motor latencies and single fibre electromyography of the external anal sphincter were performed using methods described previously.2 ${ }^{26}$

To exclude a disruption of the striated external anal sphincter ring concentric needle electromyography (mapping) was performed by multiple needle insertions. ${ }^{17}$ Defects of the internal

and external anal sphincters were further evalu-
The Sir Alan Parks Mark's Hospital, London C T M Speakman Correspondence to: Mr C T M Speakman, St Mark's Hospital, City Road, London ECIV 2PS.

Accepted for publication 13 July 1992 
TABLE I Obstetric details of patients and control subjects

\begin{tabular}{|c|c|c|c|c|}
\hline & $\begin{array}{l}\text { Healthy } \\
\text { controls } \\
(n=18)\end{array}$ & $\begin{array}{l}\text { Sphincter } \\
\text { defect } \\
(n=17)\end{array}$ & $\begin{array}{l}\text { Neurogenic } \\
\text { incontinence } \\
(n=30)\end{array}$ & $\begin{array}{l}\text { Dual } \\
\text { pathology } \\
(n=12)\end{array}$ \\
\hline $\begin{array}{l}\text { Age (y) } \\
\text { (range) } \\
\text { Mean number of obstetric } \\
\quad \text { deliveries }\end{array}$ & $\begin{array}{c}37 \\
(24-61) \\
1 \cdot 2\end{array}$ & $\begin{array}{c}44 \\
(30-66) \\
1 \cdot 8\end{array}$ & $\begin{array}{c}52 \\
(22-69) \\
2 \cdot 4\end{array}$ & $\begin{array}{c}54 \\
(35-68) \\
2 \cdot 6\end{array}$ \\
\hline $\begin{array}{l}\text { \% Who had a forceps delivery } \\
\% \text { Who had a recognised obstetric } \\
\text { tear during delivery }\end{array}$ & $\begin{array}{r}11 \\
0\end{array}$ & $\begin{array}{l}75 \\
58\end{array}$ & $\begin{array}{l}70 \\
30\end{array}$ & $\begin{array}{l}33 \\
25\end{array}$ \\
\hline $\begin{array}{l}\% \text { Previous hysterectomy } \\
\% \text { With current urinary } \\
\text { incontinence }\end{array}$ & $\begin{array}{l}6 \\
0\end{array}$ & $\begin{array}{l}17 \\
20\end{array}$ & $\begin{array}{l}23 \\
69\end{array}$ & $\begin{array}{l}20 \\
50\end{array}$ \\
\hline
\end{tabular}

ated using anal endosonography, performed with a $7 \mathrm{MHz}$ rotating transducer of $3 \mathrm{~cm}$ focal length covered with a hard sonolucent plastic cone. ${ }^{18}$ The unit was filled with degassed water for acoustic coupling. The assembled unit was lubricated, inserted with the patient in the left lateral position and serial images taken throughout the length of the anal canal.

These investigations enabled separation of the incontinent patients into three groups as follows:

(a) Those with neurogenic incontinence but an anatomically intact sphincter mechanism $(n=30$, mean age (range) 52 years (22-69)). All of these patients (neurogenic) had decreased anal pressures, prolonged pudendal nerve terminal motor latencies $(>2 \cdot 2 \mathrm{~ms})$, increased single fibre density of the external anal sphincter $(>1 \cdot 6)$, but an intact external anal sphincter on concentric needle mapping and anal endosonography.

(b) Those with normal innervation but a disrupted external anal sphincter $(n=17$, mean age (range) 44 years $(30-66)$ ). These patients (EAS defect) had decreased anal pressures, normal pudendal latencies, and normal single fibre density, but electromyographic (EMG) and endosonographic evidence of a disrupted sphincter.

(c) Those with evidence of both neurogenic damage to the striated muscles and a disrupted sphincter ( $n=12$, mean age (range) 54 years (3568)). This group of patients (dual pathology) had low pressures, prolonged pudendal nerve latencies, raised single fibre density, and concentric EMG and endosonographic evidence of an external anal sphincter defect.

The patients' obstetric and urogynaecological details are presented in Table I.

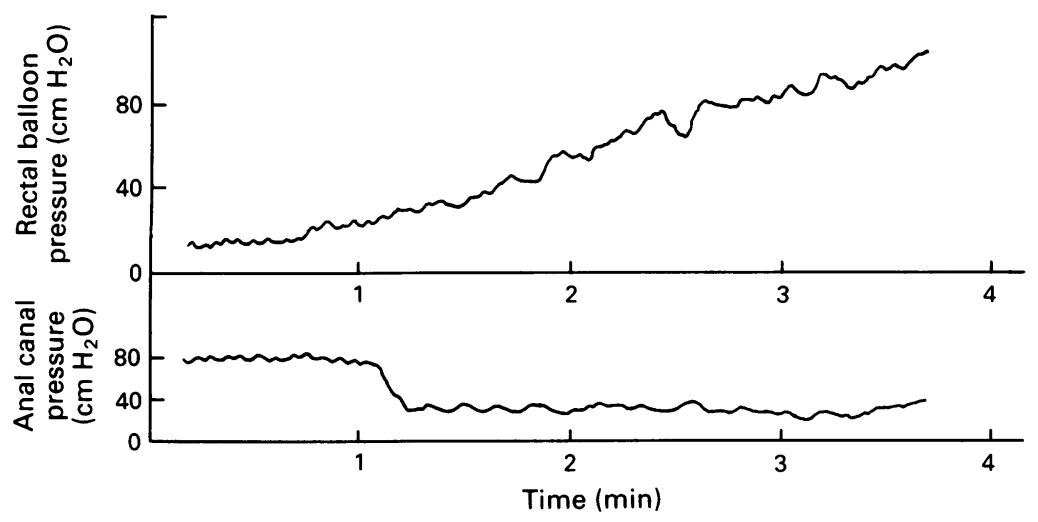

Figure 1: Rectal and anal canal pressures during rectal distension at a rate of $50 \mathrm{ml}$ per minute.

\section{HEALTHY CONTROLS}

Eighteen healthy volunteer women (mean age 37 years, range 24-61) were studied: none had a history of constipation or incontinence. Anal pressures and pudendal nerve latency measurements were performed and all were within the normal range.

The study was approved by the ethics committee of the City and Hackney Health Authority and all subjects gave informed consent.

\section{Methods}

The following tests were carried out in patients and control subjects:

\section{RECTAL SENSATION TO DISTENSION}

A lubricated rubber balloon was placed in the rectum approximately $4 \mathrm{~cm}$ above the anal canal then inflated and deflated to 'seat' it properly in the rectum. The balloon was then distended with air and the patient asked to report the initial sensation (sensory threshold), the sensation of urgency, and the maximum tolerable volume. ${ }^{19}$

RECTAL SENSATION TO ELECTRICAL STIMULATION Rectal mucosal stimulation was assessed using the technique previously described. ${ }^{20}$ The electrode was positioned in the rectum $10 \mathrm{~cm}$ from the anal verge and a stimulus of $10 \mathrm{~Hz}$ and $500 \mu$ seconds used with a gradually increasing current until the subject was able to perceive the stimulus. The stimulus was usually described by the patient as a throbbing or filling sensation. The test was repeated three times and the lowest current perceived was recorded.

\section{ANAL SENSATION TO ELECTRICAL SENSATION}

Sensation in the anal canal was assessed using a bipolar ring electrode (Dantec 21L10, Bristol, UK) mounted on a 14 G Foley catheter. The electrode was sited in mid-anal canal and connected to a constant current stimulator (Neuromatic 2000M, Dantec, UK). Stimuli of $5 \mathrm{~Hz}$ and $100 \mu$ seconds were applied to the anal canal and the current was gradually increased until the patient was able to feel the stimulus, which in the anal canal was perceived as a tingling or pricking sensation. The minimum current in milliamps at which the initial sensation was felt was noted after repeating the test three times. ${ }^{2122}$

RECTAL COMPLIANCE

This was studied using a $10 \mathrm{~cm}$ long balloon constructed from a condom attached to a double lumen polyvinyl catheter, diameter $2.5 \mathrm{~mm}$ (14J 081, Porges, France). One lumen was connected to a peristaltic pump (Watson-Marlow, Falmouth, Cornwall) while the other was connected to a pressure transducer (Medex MX-848) and the output recorded on a chart recorder (Devices MX4-73). The balloon was distended with water at a rate of $50 \mathrm{ml}$ per minute independent of intraballoon pressure. The chart recorder paper speed was $50 \mathrm{~mm} / \mathrm{minute}$, allowing easy calculation of the volume at any point of the recording. 
Electrical stimulus: $20 \mathrm{~Hz}, 1 \mathrm{~ms}$ pulse duration

$$
\begin{array}{lllllll}
5 \mathrm{~mA} & 7.5 \mathrm{~mA} & 10 \mathrm{~mA} & 12.5 \mathrm{~mA} & 15 \mathrm{~mA} & 17.5 \mathrm{~mA} & 20 \mathrm{~mA}
\end{array}
$$

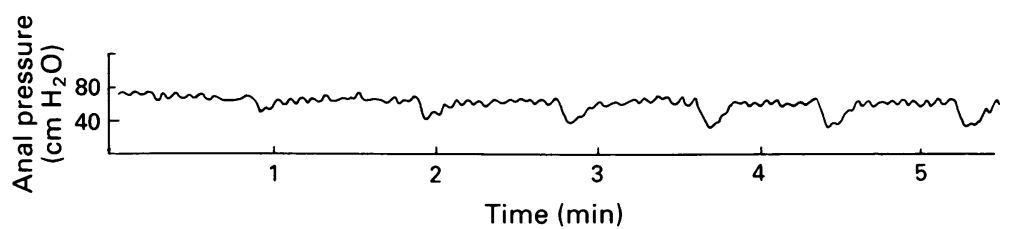

Figure 2: Electrical stimulation induced anal relaxation.

Before each study the compliance of the balloon was calculated by distension of the balloon outside the patient. Intrarectal pressures at different volumes were then calculated by subtraction of the balloon pressures measured outside the patient from those recorded during the patient study. The pressure within the condom reached a pressure of $15-18 \mathrm{~cm} \mathrm{H}_{2} \mathrm{O}$ at $100 \mathrm{ml}$ and remained constant thereafter.

With the subject in the left lateral position, the pressure in the empty rectal compliance balloon was 'zeroed' at the level of the anal verge and then inserted into the rectum. To measure anal pressure at the same time a microballoon pressure catheter was then placed in the anal canal at the site of the maximum resting anal pressure. This 4 $\mathrm{mm}$ microballoon was connected to another pressure transducer in a closed water filled system, and the pressure recorded simultaneously with the intrarectal pressure on the chart recorder (Fig 1).

During rectal distension, from 0 to the maximum tolerable volume, both the intrarectal balloon volume and pressure were noted at $50 \mathrm{ml}$ intervals. They were also noted at the volumes which produced a sensation of urgency and maximum tolerable volume. The compliance $(\mathrm{dV} / \mathrm{dP})$ between $100 \mathrm{ml}$ and the maximum tolerable volume was calculated by dividing the change in balloon volume by the corresponding change in pressure.

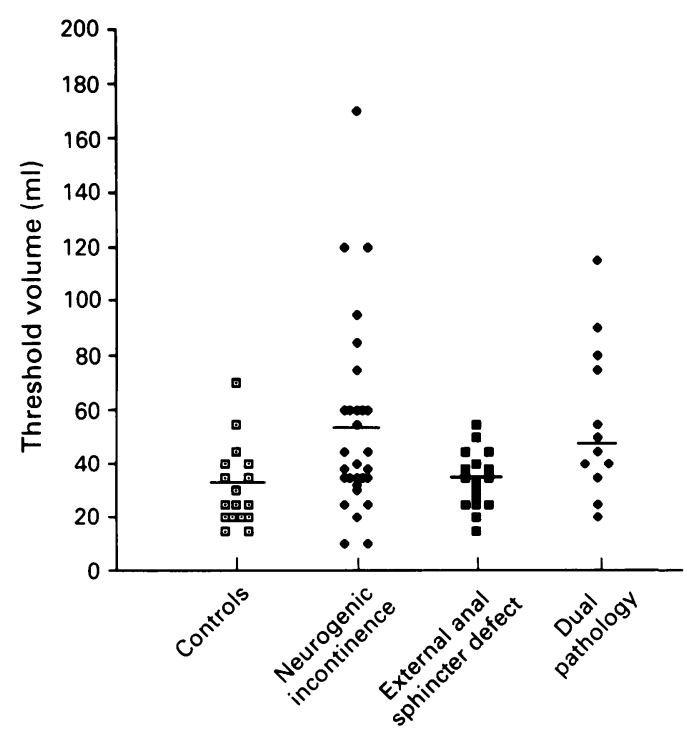

Figure 3: Rectal sensation to distension: threshold volume. There was a significant difference between controls and those with neurogenic incontinence and dual pathology.

\section{Rectal distension induced anal relaxation}

During rectal distension the resting anal pressure recorded by the microballoon in the anal canal fell. To compare the responses of the internal anal sphincter to rectal distension in the different patient groups the rectal volumes and pressures at the point of the initial fall in resting pressure were noted.

\section{Temperature and rectal compliance}

The effect of temperature on rectal compliance was assessed. In eight of the control subjects rectal compliance was performed using water at two different temperatures - at room temperature $\left(19-22^{\circ} \mathrm{C}\right)$ and at $37^{\circ} \mathrm{C}$. There was an interval of 10 minutes between recordings.

\section{ELECTRICAL STIMULATION INDUCED ANAL}

\section{RELAXATION}

This study was designed to quantitate the rectal wall current required to produce internal anal sphincter relaxation. The bipolar ring electrode (Dantec 21L10, UK) mounted on a 14 G Foley catheter was inserted into the rectum to lie $6 \mathrm{~cm}$ above the upper limit of the anal canal. The microballoon was reintroduced into the rectum and using the stationary pull through technique the site of maximum resting anal pressure was determined. The microballoon was left at this site and a stable pressure recording was obtained. The electrode was connected to a constant current stimulator (Neuromatic 2000M, Dantec, UK). A stimulus of $20 \mathrm{~Hz}$ frequency and 1 millisecond pulse duration was applied to the rectal wall, as described previously. ${ }^{2324}$ The initial stimulus was $2.5 \mathrm{~mA}$ and this was increased by increments of $2.5 \mathrm{~mA}$, allowing approximately 1 minute between each stimulation. The maximum stimulus applied was $40 \mathrm{~mA}$ or less if the stimulus was uncomfortable or three successive stimuli produced no further relaxation of the sphincter. Each stimulus was applied until maximum relaxation for that amplitude stimulus was achieved and the pressure had started to return to the baseline. When three successive stimuli failed to produce any greater fall in anal pressure (sphincter relaxation) no further stimulations were performed (Fig 2).

\section{STATISTICAL METHODS}

Normal distribution of the data was checked with the Wilk-Shapiro test of normality and the means were compared using student's unpaired $t$ test. Data are presented as mean (SEM). Data that were not normally distributed were compared using the sign rank test.

\section{Results}

\section{RECTAL SENSATION TO DISTENSION}

The mean sensory threshold volume in those with neurogenic incontinence alone and those with dual pathology was significantly higher than in controls (Fig 3). Patients with an anatomically disrupted sphincter but normal innervation did not differ from normal. 
TABLE II Mean (SEM) sensory thresholds to balloon and electrical mucosal stimulation

\begin{tabular}{|c|c|c|c|c|}
\hline & $\begin{array}{l}\text { Healthy } \\
\text { controls } \\
(n=18)\end{array}$ & $\begin{array}{l}\text { Neurogenic } \\
\text { incontinence } \\
(n=30)\end{array}$ & $\begin{array}{l}\text { Sphincter } \\
\text { defect } \\
(n=17)\end{array}$ & $\begin{array}{l}\text { Dual } \\
\text { pathology } \\
(n=12)\end{array}$ \\
\hline \multicolumn{5}{|l|}{ Rectal sensory threshold to } \\
\hline $\begin{array}{l}\text { Threshold volume (ml air) } \\
\text { Urgency volume (ml air) } \\
\text { Maximum tolerable volume } \\
\text { (ml air) }\end{array}$ & $\begin{array}{c}31 \cdot 5(3 \cdot 6) \\
65 \cdot 0(6 \cdot 4) \\
177(16 \cdot 2)\end{array}$ & $\begin{array}{c}53 \cdot 1(6 \cdot 4)^{\star} \\
93 \cdot 6(7 \cdot 8)^{\star} \\
175(10 \cdot 4)\end{array}$ & $\begin{array}{c}34 \cdot 2(2 \cdot 6) \\
66 \cdot 4(4 \cdot 3) \\
157(11 \cdot 5)\end{array}$ & $\begin{array}{c}47 \cdot 5(8 \cdot 2)^{\star} \\
87(10 \cdot 8) \\
163(15 \cdot 7)\end{array}$ \\
\hline $\begin{array}{l}\text { Rectal sensory threshold to } \\
\text { electrical mucosal stimulation: } \\
\text { Rectal sensation (mA) } \\
\text { Anal sensory threshold to }\end{array}$ & $14 \cdot 8(1.4)$ & $24 \cdot 4(1 \cdot 7)^{\star}$ & $16 \cdot 2(1 \cdot 7)$ & $22.9(3.0)^{\star}$ \\
\hline $\begin{array}{l}\text { electrical mucosal stimulation: } \\
\text { Mid-anal canal (mA) }\end{array}$ & $4 \cdot 2(0.4)$ & $7 \cdot 4(0.5)^{\star}$ & $6.9(1.4)$ & $9 \cdot 1(3.4)$ \\
\hline
\end{tabular}

$\star$ Significantly different from the control value, $\mathrm{p}<0.05$.

If the data of patients with an anatomically defective sphincter are combined with those of patients with neurogenic incontinence then there is no significant difference from controls, highlighting the importance of clear patient definition.

Patients with neurogenic incontinence, but not those with an anatomically defective sphincter without neuropathy, required a significantly greater volume to elicit a sensation of urgency than healthy controls.

There was no significant difference between the three patient groups and normals in the mean maximum tolerable volume (Table II).

RECTAL SENSATION TO ELECTRICAL STIMULATION The rectal mucosal electrical sensory threshold was also abnormal in both groups with incontinence in the presence of a neuropathy. Those with a sphincter defect alone did not have abnormal rectal sensation (Fig 4).

ANAL SENSATION TO ELECTRICAL SENSATION

The mid-anal canal sensation was abnormal in those patients with neurogenic incontinence (Table II).

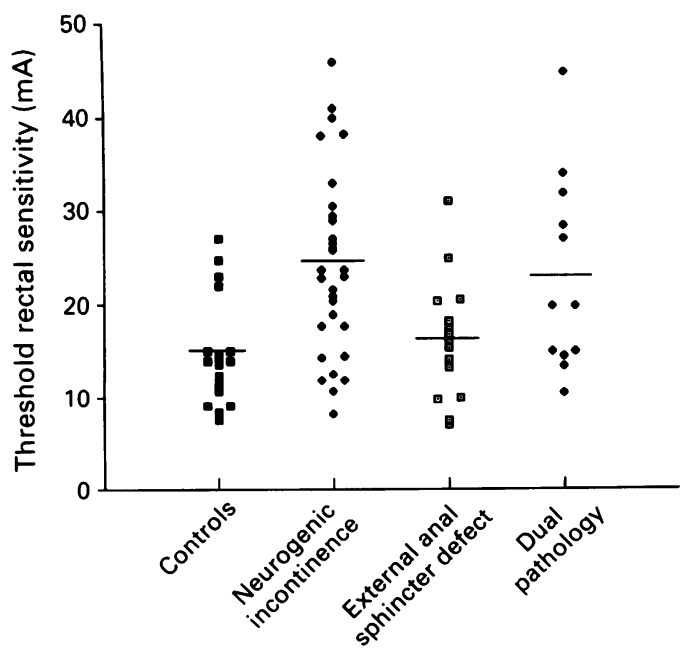

Figure 4: Threshold rectal electrical sensitivity. There was a significant difference between controls and those with neurogenic incontinence and dual pathology.
TABLE III Rectal pressures in patients with neurogenic incontinence and healthy control subjects (values mean $(S E M))$

\begin{tabular}{ccc}
\hline & \multicolumn{2}{l}{ Rectal pressures $(\mathrm{cm} \mathrm{H}, \mathrm{O})$} \\
\cline { 2 - 3 } Volume & $\begin{array}{l}\text { Healthy controls } \\
(n=18)\end{array}$ & $\begin{array}{l}\text { Neurogenic } \\
\text { incontinence } \\
(n=20)\end{array}$ \\
\hline $50 \mathrm{ml}$ & $7 \cdot 3(1 \cdot 2)$ & $7 \cdot 0(1 \cdot 0)$ \\
$100 \mathrm{ml}$ & $13 \cdot 9(2 \cdot 3)$ & $11 \cdot 7(1 \cdot 6)$ \\
$150 \mathrm{ml}$ & $18 \cdot 4(2 \cdot 6)$ & $19 \cdot 3(3 \cdot 0)$ \\
$200 \mathrm{ml}$ & $27 \cdot 3(4 \cdot 5)$ & $22 \cdot 5(3 \cdot 6)$ \\
$250 \mathrm{ml}$ & $32 \cdot 3(7 \cdot 5)$ & $30 \cdot 1(4 \cdot 8)$
\end{tabular}

There were no significant differences between the groups examined.

TABLE IV Compliance, volumes, and pressures at different rectal sensations in healthy controls and patients with neurogenic incontinence (values mean (SEM))

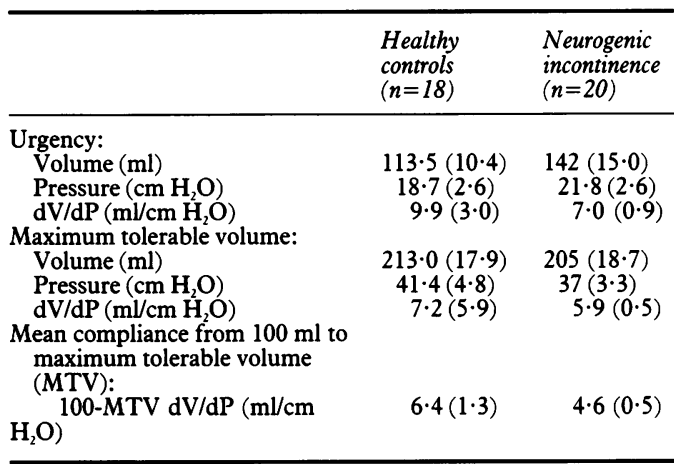

There was no significant differences between the two groups.

TABLE V Rectal balloon volumes and pressures at initial sphincter relaxations (values mean (SEM))

\begin{tabular}{lcc}
\hline & $\begin{array}{l}\text { Healthy } \\
\text { controls } \\
(n=18)\end{array}$ & $\begin{array}{l}\text { Neurogenic } \\
\text { incontinence } \\
(n=20)\end{array}$ \\
\hline $\begin{array}{l}\text { Rectal volume at 1st sphincter } \\
\text { relaxation (ml) }\end{array}$ & $31(9 \cdot 0)$ & $31 \cdot 9(6 \cdot 5)$ \\
$\begin{array}{l}\text { Rectal balloon pressure at } 1 \mathrm{st} \\
\text { sphincter relaxation }\left(\mathrm{cm} \mathrm{H}_{2} \mathrm{O}\right)\end{array}$ & $3(1 \cdot 1)$ & $4 \cdot 2(1 \cdot 2)$ \\
\hline
\end{tabular}

RECTAL COMPLIANCE

None of the parameters examined using the rectal compliance system were abnormal in any patient group (Tables III and IV). However, even within the control group a wide intersubject variation was observed. For example, the pressures recorded after $200 \mathrm{ml}$ of water had been infused into the rectal balloon ranged from 8 to $50 \mathrm{~cm} \mathrm{H} \mathrm{H}_{2} \mathrm{O}$.

Rectal distension induced anal relaxation

The mean rectal volume and pressure required to produce the initial relaxation of the anal sphincter were also similar in controls and all groups of incontinent patients (Table V). In both controls and patients the rectal pressure required to induce sphincter relaxation was very low. In six controls the rectal pressure had not perceptibly changed from the baseline when initial sphincter relaxation occurred.

\section{Rectal compliance and temperature}

In the eight controls in whom rectal compliance was performed at two temperatures there was no 


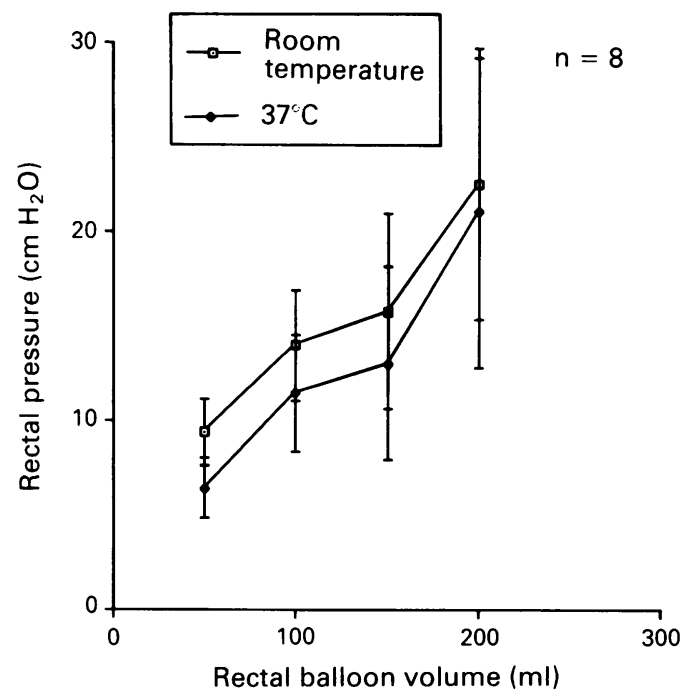

Figure 5: Rectal compliance at different temperatures in eight control subjects.

significant difference in the pressures at given volumes or the maximum tolerable volume in the two studies (Fig 5).

\section{ELECTRICAL STIMULATION INDUCED ANAL RELAXATION}

The threshold for sphincter relaxation was below the threshold for conscious perception of the stimulus in all control cases.

In three patients with neurogenic incontinence and two with normal innervation but sphincter defects there was no anal sphincter response to electrical stimulation. This was not caused by failure of contact between the electrode and the rectal wall - the constant current stimulator indicates when the current is not being delivered. These five patients had low resting anal pressures which probably accounted for the lack of an observed fall in pressure.

The mean stimulus required to produce an initial relaxation was not significantly different in the groups examined (Table VI). The stimulus required for maximum relaxation was also not different from controls.

\section{Discussion}

Female patients with faecal incontinence are not a homogeneous group in terms of pathogenesis. During childbirth some patients sustain a disruption of the sphincter complex, in the absence of an obvious tear, which may not be apparent at the time of delivery. This is surprisingly common, occurring in more than $30 \%$ of primiparous deliveries. ${ }^{25}$ Other patients sustain nerve damage to the pudendal nerve which leads to progressive denervation and incontinence later in life. Some patients sustain both these injuries leading to a mixed picture. In those with a purely mechanical disruption but intact pelvic floor neurological function one might expect the hind gut innervation, as assessed by sensory tests, to be normal. Indeed this study has shown that patients with a sphincter defect alone have normal rectal sensation, those with a pudendal neuropathy or mixed aetiology have impaired
TABLE VI Electrical rectal stimuli required to produce initial and maximum relaxation of the internal anal sphincter

\begin{tabular}{llll}
\hline & $\begin{array}{l}\text { Healthy } \\
\text { controls } \\
(n=18)\end{array}$ & $\begin{array}{l}\text { Neuropathy } \\
(n=15)\end{array}$ & $\begin{array}{l}\text { EAS } \\
\text { defect } \\
(n=11)\end{array}$ \\
\hline $\begin{array}{l}\text { Threshold (mA) for } \\
\text { relaxation }\end{array}$ & $11.5(1 \cdot 0)$ & $12.9(0.9)$ & $10(1 \cdot 3)$ \\
$\begin{array}{c}\text { Stimulus for maximum } \\
\text { relaxation }\end{array}$ & $23.5(1.4)$ & $23.9(1.5)$ & $20(2 \cdot 1)$ \\
\hline
\end{tabular}

There were no significant differences between the groups. EAS=external anal sphincter.

sensation, and that this difference is obscured if these groups are not correctly identified and separated.

Abnormal balloon distension thresholds in patients with incontinence have been described in several reports ${ }^{6-11}$ but other groups have found no difference. ${ }^{12-15}$ It seems likely that these latter studies have combined groups of patients with different pathophysiological causes for incontinence. In the incontinent group described by Wald and Tunuguntla, ${ }^{12} 10$ of the 31 had incontinence associated with anorectal surgery or disease, two had childhood encopresis, and one had had an ileal resection. Likewise Rasmussen et al ${ }^{14}$ combined 15 patients with idiopathic faecal incontinence and 16 patients with incontinence of traumatic origin. In the study by Penninckx et $a l^{13}$ only four of the patients had evidence of pudendal neuropathy. Ferguson et al ${ }^{15}$ selected patients with neurogenic incontinence only but one third of their control group were men; as a result the mean balloon distension sensory threshold was approximately $50 \mathrm{ml}$, which is considerably higher than that in most reports using the same technique..$^{12} 20$

Our studies show a disturbance of visceral sensation to both balloon distension and electrical mucosal stimulation in patients with neurogenic incontinence. Women with incontinence because of a sphincter tear but normal innervation had reduced anal pressures but normal visceral sensation.

Our control group was younger than that with neurogenic faecal incontinence alone (Table 1). However the patients with a sphincter disruption without neuropathy also acted as a separate disease control group, and there was no significant difference in age between this group and that with a neuropathy alone. Furthermore, Allen $e t$ al found no change in the threshold for balloon distension with age. ${ }^{9}$ We therefore feel that the observed abnormality of rectal sensation in these patients is a true finding. Similarly, the observed normal compliance in our incontinent patients is likely to be a true finding, as previous studies have shown either no change ${ }^{26}$ or a decrease in compliance with age..$^{27}$

A raised threshold for electrical stimulation in patients with neurogenic incontinence indicates a true sensory abnormality rather than a larger rectum in these subjects. This test is not affected by variations in rectal capacity or rectal wall compliance. Electrosensitivity is likely to be mediated via different receptors and pathway than the sensation induced by distension. The rectal mucosa is known to be innervated by nonmyelinated nerve fibres ${ }^{29}$ which are probably 
excited by electrical, ${ }^{23}$ thermal ${ }^{30}$ and mechanical stimulation. The perception of rectal distension probably depends on receptors in the rectal wall ${ }^{31}$ or even the configuration of the intrinsic nerve plexuses, and may also involve receptors in the mesentery or in the pelvic floor. ${ }^{32}$ Parasympathetic $^{33}$ and sympathetic nerves may be involved in conveying afferent rectal sensory fibres from the rectum.

Our finding of normal rectal compliance in patients with faecal incontinence confirms that of others ${ }^{1234-36}$ and suggests that the passive viscoelastic properties of the rectal wall are normal in this condition. However, the wide variation in compliance in controls and patients ${ }^{37}{ }^{38}$ makes it unlikely that this technique would reliably detect changes in the rectal wall unless the differences are considerable.

The low rectal pressures and volumes required to produce inhibition of the sphincter suggest that the rectoanal inhibitory reflex may not depend solely on volume or pressure receptors. Indeed, the rectoanal reflex can be produced by electrical or thermal stimulation without rectal distension probably via receptors within the mucosa. Recent work from our laboratory suggests that sphincter relaxation occurs early during defaecation before peristalsis reaches the rectum, ${ }^{39}$ and that this sphincter relaxation is likely to be mediated via intrinsic intracolonic and intrarectal nerves. ${ }^{24}$

The normal response of the internal anal sphincter to two distinct types of rectal stimulation, that is rectal electrical stimulation and distension, in patients with incontinence suggests that the intrinsic innervation is normal. In contrast, using balloon distension as a stimulus, Read et al found that the volume required to produce the rectoanal inhibitory reflex by balloon distension was lower in incontinent subjects. ${ }^{40}$ However, in a separate study ${ }^{5}$ the same group found that $10 \%$ of patients with idiopathic faecal incontinence had abnormal rectal sensation together with normal distension volumes required to elicit anal relaxation - a finding similar to our own. The fact that a number of patients with low resting pressures had no response to electrical stimulation suggests that these patients either had a more severe abnormality affecting the internal anal sphincter or that for some reason they have an abnormality of their intrinsic innervation. Sun et al also described a subgroup of incontinent patients with noticeably abnormal function of the internal anal sphincter in whom there was no detectable relaxation in response to rectal distension. ${ }^{10}$

In summary, the passive viscoelastic properties of the rectal wall are normal in neurogenic incontinence. Our findings of altered sensation to distension and electrical stimulation therefore suggest a probable primary visceral neurological deficit. The intrinsic innervation of the internal anal sphincter, as assessed by the response to rectal distension and electrical stimulation, is normal. We therefore feel that the abnormality in hindgut visceral neurological function is more likely to involve the extrinsic nerve supply, than the intrinsic nerves.

In neurogenic faecal incontinence, extrinsic denervation affects more than just the sphincter mechanism - afferent pathways from the rectum, at least, also seem to be affected.

C T M Speakman is supported by the Sir Alan Parks Research Foundation, The Royal College of Surgeons and M A Kamm by the St Mark's Research Foundation.

1 Parks AG, Swash M, Urich H. Sphincter denervation in anorectal incontinence and rectal prolapse. Gut 1997; 18 656-65.

2 Neill ME, Swash M. Increased motor unit fibre density in the external anal sphincter muscle in anorectal incontinence: a single fibre EMG study. F Neurol Neurosurg Psychiatry 1980; 43: $343-7$.

3 Goligher JC, Hughes ESR. Sensibility of the rectum and colon: its role in the mechanism of anal continence. Lance colon: its role in

4 Whitehead WE, Orr WC, Engel BT, Schuster MM. External anal sphincter response to rectal distention: learned response or reflex. Psychophysiology 1982; 19: 57-72.

5 Sun WM, Read NW, Miner PB. Relation between rectal sensation and anal function in normal subjects and patients with faecal incontinence. Gut 1990; 31: 1056-61.

6 Womack NR, Morrison JFB, Williams NS. Anal continence depends on sphincter recruitment by stress rather than absolute sphincter strength. Br F Surg 1989; 76: A636.

7 Womack NR, Morrison JFB, Williams NS. The role of pelvic floor denervation in the aetiology of idiopathic faecal incontinence. Br f Surg 1986; 73: 404-7.

8 Buser WD, Miner PB. Delayed rectal sensation with fecal incontinence. Gastroenterology 1986; 91: 1186-91.

9 Allen ML, Orr WC, Robinson MG. Anorectal functioning in fecal incontinence. Dig Dis Sci 1988; 33: 36-40.

10 Sun WM, Read NW, Donnelly TC. Impaired internal ana sphincter in a subgroup of patients with idiopathic faecal incontinence. Gastroenterology 1989; 97: 130-5.

11 Bielefeldt K, Enck P, Joachim FE. Sensory and moto function in the maintenance of anal continence. Dis Colon Rectum 1990; 33: 674-8.

12 Wald A, Tunuguntla AK. Anorectal sensorimotor dysfunction in fecal incontinence and diabetes mellitus. $N$ Engl $\mathcal{F} M e d$ 1984; 310: 1282-7.

13 Penninckx FM, Lestár B, Kerremans RP. A new balloonretaining test for evaluation of anorectal function in incontinent patients. Dis Colon Rectum 1989; 32: 202-5.

14 Rasmussen $O$, Christensen B, Sorensen $M$, Tetzschener $T$ Christiansen J. Rectal compliance in the assessment of patients with fecal incontinence. Dis Colon Rectum 1990; 33 650-3.

15 Ferguson GH, Redford J, Barrett JA, Kiff ES. The appreciation of rectal distention in fecal incontinence. Dis Colon Rectum 1989; 32: 964-7.

16 Kiff ES, Swash M. Slowed conduction in the pudendal nerve in idiopathic (neurogenic) faecal incontinence. $B r \mathcal{F}$ Surg 1984; 71: 614-6.

17 Lubowski DZ, Swash M, Henry MM. Neural mechanisms in disorders of defaecation. In: Grundy D, Read NW, eds. Baillière's Clinical Gastroenterology: Gastrointestinal NeuroBaillière's Clinical Gastroenterology: Gastrointestinal
physiology. London: Baillière Tindall, 1988: 216-7.

18 Law PJ, Bartram CI. Anal endosonography: technique and normal anatomy. Gastrointest Radiol 1989; 14: 349-53.

19 Henry MM, Snooks SJ, Barnes PRH, Swash M. Investigations of disorders of the anorectum and colon. Ann R Coll Surg 1985; 67: 355-60.

20 Kamm MA, Lennard-Jones JE. Rectal mucosal electrosensory testing - evidence for a rectal sensory neuropathy in idiopathic constipation. Dis Colon Rectum 1990; 33: 419-23.

21 Roe AM, Bartolo DCC, Cervero F, Mortensen NJMcC. New method for assessment of anal sensation in various anorecta disorders. Brf Surg 1986; 73: 310-2.

22 Rogers J, Henry MM, Misiewicz JJ. Combined sensory and motor deficit in primary neuropathic faecal incontinence. Gut 1988; 29: 5-9.

23 Nagasaki A, Ikeda K, Suita S, Sumitomo K. Induction of the rectoanal reflex by electrical stimulation. A diagnostic aid for rectoanal reflex by electrical stimulation. A diagnostic aid for

24 Kamm MA, Lennard-Jones JE, Nicholls RJ. Evaluation of the intrinsic innervation of the internal anal sphincter using electrical stimulation. Gut 1989; 30: 935-8.

25 Sultan AH, Kamm MA, Hudson CN, Bartram CI. Ana sphincter disruption in $32 \%$ of vaginal deliveries: a prospective ultrasound study. Gut 1992; 33: S66.

26 Devroede G, Vobecky S, Masse S, Ahran P, Leger C, Duguay $\mathrm{C}$, et al. Ischaemic fecal incontinence and rectal angina. Gastroenterology 1982; 83: 970-80.

27 Ihre T. Studies on anal function in continent and incontinen patients. Scand $\mathcal{F}$ Gastroenterol 1974; 9 (suppl 25).

patients. Scand Gastroenterol 1974; 9 (suppl 25). anorectal function. Gut 1987; 28: 353-7.

29 Duthie HL, Gairns FW. Sensory nerve-endings and sensation in the anal region of man. Brf Surg 1960; 47: 585-94.

30 Nagasaki A, Ikeda K, Sumitomo K. Rectoanal reflex induced by $\mathrm{H}_{2} \mathrm{O}$ thermal stimulation. Dis Colon Rectum 1989; 32: by $\mathrm{H}_{2} \mathrm{O}$

31 Parks AG, Porter NH, Melzak J. Experimental study of the reflex mechanism controlling the muscles of the pelvic floor. reflex mechanism controlling the m
Dis Colon Rectum 1962; 5: 407-14.

32 Scharli AF, Kiesewetter WB. Defecation and continence: some new concepts. Dis Colon Rectum 1970; 13: 81-107.

33 Last RJ. Anatomy - regional and applied. 7 th ed. Edinburgh: Churchill Livingstone, 1984: 328-9. 
34 Read NW, Haynes WG, Bartolo DCC, Hall J, Read MG, Donnelly TC, et al. Use of anorectal manometry during rectal infusion of saline to investigate sphincter function in rectal infusion of saline to investigate sphincter function
incontinent patients. Gastroenterology 1983; 85: 105-13.

35 Penninckx FM, Lestár B, Kerremans RP. A new balloonretaining test for evaluation of anorectal function in incontinent patients. Dis Colon Rectum 1989; 32: 202-5.

36 Bartolo DCC, Read NW, Jarratt JA, Read MG, Donnelly TC, Johnson AG. Differences in anal sphincter function and clinical presentation in patients with pelvic floor descent. Gastroenterology 1983; 85: 68-75.

37 Åkervall S, Fasth S, Nordgren S, Öresland T, Hultén L.
Rectal reservoir and sensory function studied by graded isobaric distension in normal man. Gut 1989; 30: 496-502. 38 Kendall GPN, Thompson DG, Day SJ, Lennard-Jones JE. Inter- and intraindividual variation in pressure-volume relations of the rectum in normal subjects and patients with irritable bowel syndrome. Gut 1990; 31: 1062-8.

39 Kamm MA, van der Sijp JRM, Lennard-Jones JE. Colorectal and anal motility during defaecation. Lancet 1992; 339: 820 . 40 Read NW, Bartolo DCC, Read MG. Differences in anal function in patients with incontinence to solids and in patients with incontinence to solids and in patients with incontinence to liquids. BrF Surg 1984; 71: 39-42. 